\title{
ENTRE O HORROR E A BELEZA: A SUBLIME ESTÉTICA GÓTICA DOS FILMES DE GUILLERMO DEL TORO
}

Alessandro Yuri Alegrette (UNESP- FCL - Araraquara)

Recebido em 09 mar 2016. Alessandro Yuri Alegrette - Professor bolsista FAPESP. Aprovado em 20 abr 2016. Mestre e doutorando em Estudos Literários. (UNESP) - Faculdade de Ciências e Letras - Programa de PósGraduação em Estudos Literários. Araraquara - SP - Brasil. Contato: alessandroyuri@bol.com.br ou alealegrette@gmail.com.

Resumo: Este artigo procura apontar alguns aspectos peculiares e importantes sobre a criação de efeitos de horror nos filmes Cronos, A Espinha do Diabo e $O$ Labirinto do Fauno dirigidos pelo diretor mexicano Guillermo Del Toro. Em sua filmografia, Del Toro revisita temas e motivos encontrados em um gênero, que contribuiu de forma significativa para a evolução e popularização do horror cinematográfico: o gótico. Além disso, todos os filmes de Del Toro têm cenas de grande impacto visual, nas quais é criada uma relação de ambivalência entre o horripilante e a beleza. Assim, procuramos demonstrar a sublime estética das produções de Del Toro, que tem suas origens na tradição gótica inglesa dos séculos XVIII e XIX, nos contos de fadas e em narrativas de autores do terror moderno, tais como H. P. Lovecraft e também nos filmes clássicos de horror gótico. 
Palavras-chave: Cinema; Guillermo Del Toro; Gótico; Horror; Sublime.

Abstract: This paper aims to point out some peculiar and important aspects about the creation of horror effects in the films, such as Cronos, The Devil's Backbone and Pan's Labyrinth directed by Mexican director Guillermo Del Toro. In his filmography, Del Toro revisits themes, motifs found in a genre, which contributed significantly to the development and popularization of horror movie: the Gothic. Besides, all Del Toro's films have scenes of great visual impact, in which an ambivalent relation between creepy and beauty is created. Therefore, we seek to show the sublime aesthetic of productions directed by Del Toro, that have their origins in the Gothic tradition of the eighteenth and nineteenth centuries, in the fairy tales and in the narratives of authors of modern terror, such as H.P. Lovecraft and also in the classic Gothic horror films.

Keywords: Movies; Guillermo Del Toro; Gothic; Horror; Sublime.

\section{INTRODUÇÃO}

A arte cinematográfica tem surgimento um ano antes que Drácula, uma das obras mais importantes da literatura gótica, fosse publicada e produzisse entre os leitores ingleses sensações intensas de horror, por meio de uma profusão de assustadoras imagens. Durante o final do século XIX e início do $\mathrm{XX}$, a arte cinematográfica visou causar o estranhamento e o medo nos expectadores. Isso ocorreu, principalmente, por causa da forte influência do Expressionismo, um movimento estético 
que explorou o sobrenatural, o macabro, o sensacionalismo, e amplamente difundido na Europa em várias áreas do campo das artes. Entre as produções expressionistas que contribuíram de forma significativa para a gênese do chamado "cinema de horror", destaca-se O Gabinete do Dr. Caligari (1920). Nessa produção, encontramos vários elementos que definem esse gênero: cenários abstratos, a ênfase na perspectiva distorcida da realidade, e, principalmente a sinistra caracterização de um de seus protagonistas, Cesare (Conrad Veidth), com traços fisionômicos, que o tornam parecido com um zumbi.

Alguns anos depois, na Alemanha é lançado um filme expressionista que se tornou um clássico do horror: Nosferatu: uma sinfonia de horrores (1922), de F. W. Murnau, uma livre e não autorizada adaptação de Drácula. De acordo com Phillip Kemp, o Conde Orlock (Max Schreck) é o mais horrendo vampiro do cinema, uma vez que sua imagem causa uma imediata reação de horror repulsivo nos expectadores. Magro como um cadáver, careca, com uma aparência sinistra que faz lembrar diversos tipos de roedores e também um morcego, ele se move com as mãos em forma de garra coladas aos lados do corpo, como se nunca conseguisse libertar-se do formato de seu caixão diurno (2011, p.46). O filme de Murnau também investiu na criação de cenas apavorantes. Naquela que se tornou emblemática para criação do horror artístico no cinema, a sombra de Orlock alastra-se de forma ameaçadora na parede em direção ao quarto de sua vítima, a indefesa Ellen (Greta Schröder) que é obrigada a sacrificar a própria vida para destruí-lo. 
Posteriormente, na década de trinta foi produzida uma série de filmes nos Estados Unidos, baseados em obras clássicas da literatura gótica escritas por Mary Shelley, Bram Stoker e Robert Louis Stevenson. Assim, criou-se a chamada estética gótica hollywoodiana, constituída por inesquecíveis imagens de florestas, cemitérios, castelos envolvidos por uma espessa névoa e de criaturas monstruosas, tais como o Conde Drácula, a criatura monstruosa de Frankenstein e Mr. Hyde que se tornaram icônicas e foram integradas ao nosso imaginário coletivo.

\section{O ROMANCE GÓTICO}

Podemos entender o surgimento do estilo gótico, - que, posteriormente, possibilita o aparecimento do que popularmente conhecemos como "horror" -, a partir de três perspectivas: como uma resposta emocional ao excesso de racionalismo propagado pela Doutrina Iluminista no século XVIII, uma manifestação artística que promoveu a revalorização de mitos, lendas e narrativas que evocam a época medieval, e, principalmente a criação de um gênero literário que faz a retomada com grande força do efeito do sublime. O filósofo inglês Edmund Burke (1729-1797) define o conceito de sublime da seguinte forma:

Tudo que seja de algum modo capaz de incitar as ideias de dor ou de perigo, isto é, tudo que seja de alguma maneira terrível ou relacionado a objetos terríveis ou atua de um algum modo análogo ao terror que constitui uma fonte do sublime, isto é, produz a mais forte emoção, porque estou convencido de que as ideias de dor são muito mais poderosas do que aquelas que provêm do prazer (1993, p.48). 
É, principalmente na representação do espaço, que é criada essa sensação de terror prazeroso nos romances góticos: os castelos são cheios de armadilhas, armários induzem a claustrofobia, os corredores são pequenos e apertados (HAGGERTY, 1989, p.20).

Os protagonistas dos romances góticos seguem padrões e tipos, podendo ser grotescos e monstruosos, mas sempre possuindo um forte apelo emocional para o leitor (o qual torce a favor da mocinha em perigo, e contra o vilão abominável, capaz de cometer terríveis atos para obter o que deseja). Após o imenso sucesso de $O$ Castelo de Otranto (1764) entre os leitores à época, o romance gótico torna-se um fenômeno cultural na Inglaterra. Contudo, no final do século XVIII devido à exploração exaustiva de seus elementos, esse tipo de literatura entra em processo contínuo de esgotamento e desgaste. Com isso, os autores de literatura gótica buscaram novas formas de aterrorizar seus leitores, e, assim surgiram narrativas que exploram amplamente o elemento sobrenatural visando a criar eficientes efeitos de horror.

É importante esclarecer que existem diferenças entre o terror e horror. Enquanto o terror concretiza-se no plano subjetivo a partir das impressões de um personagem sobre uma determinada situação que ele não consegue compreender muito bem e, por isso, torna-se perigosa, o horror se configura a partir de seu contato direto com algo que é abjeto, capaz de provocar-lhe uma imediata e intensa sensação de repulsa e também está associado com a morte. Noël Carroll explica a natureza do horror:

A palavra "horror" deriva do latim "horrore" - ficar em pé (com o cabelo em pé) ou eriçar - e do francês antigo "orror" - eriçar ou arrepiar. E embora não 
seja preciso que o nosso cabelo fique em pé quando estamos artisticamente horrorizados, é importante ressaltar que a concepção original da palavra a ligava a um estado fisiológico anormal (do ponto de vista do sujeito) da agitação sentida. (1999, p.41)

Dessa forma, podemos notar que o efeito de horror essencialmente se faz a partir do surgimento de intensas emoções. Ele se manifesta com uma resposta emocional de nosso corpo, tais como um movimento de recuo, ou sua total paralisia. Ou seja, para que se concretize, o efeito de horror sempre é suscitado a partir de uma cena que seja capaz de alterar nosso estado emocional, de modo que possamos sair de uma zona de conforto e sentir uma sensação em que estejam misturados dor e prazer ao mesmo tempo.

Essa nova estética do horror com ênfase nas manifestações sobrenaturais tem como principais representantes The Monk (1796), de Matthew Lewis e Frankenstein (1818), que expõe o aspecto sinistro da especulação científica. Este romance escrito por Mary Shelley é protagonizado por um ser monstruoso, - ao contrário do que muitos pensam, ele não tem nome, é chamado apenas de "a criatura" -, criado a partir de um experimento macabro realizado por um estudante de Ciências Naturais chamado Victor Frankenstein. Vale ressaltar que o monstro, apesar de sua horrenda aparência, é capaz de inspirar compaixão no leitor. Ele é terrível em seu aspecto físico, mas é dotado de uma gama de sentimentos que o tornam mais humano que seu criador.

Podemos afirmar que a criatura imaginada por Mary Shelley é muito diferente das outras que apareceram nas telas de cinema. Enquanto em sua versão cinematográfica mais conhecida, que foi 
lançada nos cinemas em 1931, o monstro aparece como um ser idiotizado que se comunica somente por meio de gestos e sons guturais, no texto original de Shelley, ele fala de forma eloquente e tem discussões de cunho filosófico com seu criador, que remetem à sua natureza incomum e assustadora. Além disso, essa criatura demonstra intenso sofrimento devido a sua condição miserável, que a condena ao isolamento e autodestruição.

É a partir de Frankenstein que o romance gótico ganha novas matizes: a estética do horror adquire uma forte conotação metafórica que exprime medos e ansiedades da época, principalmente sobre os rumos da Ciência, além de demonstrar a rejeição diante de tudo que é considerado anormal ou diferente dentro da cultura inglesa. Também durante o século XIX, o romance gótico passa por um processo radical de transformação e mudança. Assim, os autores que se dedicam a criação de textos góticos adotam novas estratégias de narração, e também incorporam em sua escrita elementos composicionais de obras realistas.

Dessa forma, o gótico invade a esfera do ambiente inglêsvitoriano doméstico, provocando sua desestabilização. Os romances das irmãs Brontë - Jane Eyre e $O$ Morro dos Ventos Uivantes, ambos publicados em 1847, promovem a inserção de seres fantasmagóricos ou bestiais em casas sinistras e decadentes. Neste espaço assustador, seus habitantes se sentem ameaçados, quando eles são envolvidos em situações extraordinárias que desafiam as leis naturais.

Durante a metade do século XIX, o gótico como forma literária incorpora-se amplamente na esfera do "realismo", revelando os horrores e terrores reais que se escondem por trás das ruas 
e bairros da cidade de Londres. Dessa forma, o gótico tornarse um eficiente artifício de narração utilizado por escritores, tais como Charles Dickens. Em seus romances mais conhecidos David Copperfield (1850), Bleak House (1853) e Grandes Esperanças (1861), Dickens revela por meio do que podemos chamar de "modo de escrita gótico" a existência de uma sociedade, em que predomina a injustiça e desigualdade, constituída por seres frágeis explorados ou ameaçados por indivíduos perigosos, ambiciosos e "degenerados".

Vale lembrar que as últimas décadas dessa época são marcadas por vários tipos de ameaças de caráter sexual ou criminal atreladas à degeneração física que possibilitaram o revigoramento do gótico como forma literária (BOTTING, 1996, p.136). Nesse período, esse gênero reafirma-se em importantes obras que retomam e lançam uma nova perspectiva sobre o duplo, um de seus principais temas, a exemplo de $O$ Médico e o Monstro (1886), de Robert Louis Stevenson e O Retrato de Dorian Gray (1891), de Oscar Wilde. Em 1897, é publicado o romance que faz uma síntese do gótico do final do século XIX: Drácula, de Bram Stoker. Apesar de haver outras histórias sobre o tema do vampirismo anteriores à publicação do livro de Stoker, em seu enredo encontramos sua representação mais assustadora, marcante e duradoura.

Nesse livro de Stoker, o efeito de horror se faz a partir da mordida do vampiro, que de imediato provoca a metamorfose do corpo, desumanizando-o gradativamente, tornando-o abjeto e ameaçador. Como se vê, além de ter contribuído para a continuidade do gótico até o tempo atual, Drácula, assim como Frankenstein têm um papel significativo para a evolução e popularização do cinema de horror. 


\section{A SUBLIME ESTÉTICA GÓTICA DOS FILMES DE GUILHERMO DEL TORO}

Guillermo Del Toro nasceu em Guadalajara, na cidade do México em 1965. De acordo com Del Toro, sua aparência estranha possibilitou sua imediata identificação com os seres monstruosos e solitários, principalmente o monstro de Frankenstein. Na infância, ele tornou-se um leitor compulsivo, e também demonstrou que tinha talento para desenhar. As ilustrações criadas por Del Toro demonstram sua fértil imaginação - um traço marcante que o diretor compartilha com os personagens de seus filmes, tais como Ofélia, a protagonista de $O$ Labirinto do Fauno -, e foram registradas em seus cadernos de anotações, que de acordo com ele, consiste em uma ferramenta útil dentro de seu processo criativo.

No livro, Guillermo Del Toro: Cabinet of Curiosities - My Notebooks, Collections e Others Obsessions, escrito por ele com a colaboração do jornalista Marc Scott Zicree, o diretor mexicano afirma que para criar o aspecto visual de suas produções inspirou-se em pinturas pré-rafaelitas e simbolistas, que aludem aos impulsos humanos e também ao mítico, o mistério e o sobrenatural (DEL TORO; ZICREE 2013, p.56). Del Toro também tem um vasto conhecimento em literaturas de várias vertentes, muitas delas inseridas na esfera do fantástico. Ele cresceu lendo romances góticos dos séculos XVIII e XIX, livros de Charles Dickens, contos de terror escritos por Edgar Allan Poe e H. P. Lovecraft, histórias da Cripta do Horror e publicações similares e narrativas de crime mistério/suspense.

O cinema clássico de horror também exerceu uma forte influência sobre Del Toro, e contribui de forma significativa para 
sua formação como diretor. Seu apreço por filmes desse gênero, produzidos nas décadas de trinta e quarenta, está demonstrada em vários ambientes de Bleak House, - uma clara referência a Casa Sombria, de Dickens -, um sobrado construído em estilo gótico, que ele utiliza como local de trabalho e também abriga diferentes tipos de objetos (bonecos, pinturas, gravuras, maquetes, cartazes, etc.) que inspiram suas criações.

Zicree afirma que o elemento central dos filmes de Del Toro é sempre o medo. Para o jornalista as produções cinematográficas de Del Toro não são mais fáceis de serem classificadas. Elas podem ser vistas como fantasias sombrias, mas não do tipo escapista ou apelativa. Zicree enfatiza que o elemento fantástico na cinematografia de Del Toro é usado para interpretar o mundo, criando uma espécie de realidade alternativa, na qual o expectador possa sentir à vontade e negar a existência de eventos reais. $\mathrm{O}$ cineasta mexicano também compartilha dessa ideia e salienta que, na sua concepção, a fantasia consiste, acima de tudo, em um meio eficiente para decifrar a realidade (DEL TORO; ZICREE, 2013, p.17).

No âmbito mais amplo, Guillermo Del Toro é considerado um diretor de "cinema fantástico", uma vez que em seus filmes a realidade é sempre invadida por forças sobrenaturais, ou ela aparece atrelada a um mundo paralelo, onde ocorrem situações extraordinárias. Neste aspecto, a obra cinematográfica de Del Toro assemelha-se a de outro diretor, que também demonstra interesse por tudo aquilo que foge da esfera do real e aparece associado com o onírico, o maravilhoso e o macabro: Tim Burton. $\mathrm{O}$ diretor mexicano também compartilha outro traço de familiaridade com Burton. Assim como Del Toro, Burton foi uma 
criança solitária e também muito precoce começou a fazer curtasmetragens, em que os monstros são mostrados como simpáticos e amistosos (WOODS, 2011, p.8).

Outro ponto de aproximação entre Burton e Del Toro é o aspecto visual dos filmes de ambos os diretores, que pode ser definido como assustador e belo ao mesmo tempo. Podemos afirmar que eles conseguem criar cenas de forte impacto visual, que se destacam por sua "horrível beleza". Sobre os aspectos peculiares desta categoria estética, Mario Praz comenta:

Dessa forma, a descoberta do horror como fonte de deleite e beleza terminou por agir sobre o conceito de beleza. O elemento horrível foi integrado ao que era considerado belo, resultando no surgimento de uma nova categoria estética: a "beleza horrível" que é capaz de suscitar o efeito do "horror prazeroso", por meio da descrição de cenas e imagens (1999, p.45).

Pelo que se vê, a afirmação de Praz sintetiza muito bem o conceito de horrível beleza. Nas produções assinadas por Burton e Del Toro, o feio, o horripilante e o macabro pela forma como configuram-se, tornam-se belos aos olhos dos espectadores. Além disso, os diretores para produzirem as exuberantes imagens de seus filmes, retomam e dão uma nova roupagem a motivos, temas e cenários que podem ser encontrados no gótico em suas diversas manifestações no cinema e na literatura.

Em sua estreia como diretor de longa-metragem, com o filme Cronos (1993), Del Toro faz uma releitura de uma criatura mítica que tem suas origens na literatura gótica: o vampiro. No entanto, ao contrário de seres sedutores que aparecem em outras 
produções, o vampiro do filme de Del Toro não tem nada de especial. Ele é um homem solitário que, gradativamente, torna-se uma criatura abjeta e perigosa.

A trama do filme começa com um prólogo que relata a fabricação de um objeto feito de ouro cheio de engrenagens, capaz de prolongar a vida humana, chamado Cronos, - uma referência à divindade greco-romana que devorou os próprios filhos dentre eles, Júpiter, porque temia que eles tomassem seu lugar, e assim representa o lado negativo do tempo, como algo que é capaz de destruir.

Contudo, devido a motivos pouco esclarecidos, o alquimista se arrepende do que fez e decide esconder o estranho artefato dentro da estátua de anjo. Em seguida, há um salto temporal na narrativa, e logo depois ele morre em um terremoto. Quando seu corpo é encontrado, os legistas descobrem que esse homem tem mais de cem anos. Muito tempo depois, Jesús Gris (Frederico Luppi), um antiquário, descobre o segredo oculto nessa antiga estátua. Sem nenhuma explicação, quando o misterioso artefato medieval é examinado, este adquire vida e agindo como um ser vivo finca suas garras nas mãos de Gris, provocando feridas em suas mãos que sangram. Após esse estranho incidente, a vida do antiquário sofre uma drástica mudança. Gradativamente, ele começa a demonstrar sinais que está passando por um processo de metamorfose biológica.

Apesar de nenhum personagem mencionar a palavra vampiro durante todo filme, o expectador percebe que Jesús Gris gradativamente transforma-se nessa monstruosa criatura. Ele adota 
um comportamento animalesco que se manifesta inicialmente a partir de intensa sede e um desejo incomum de ingerir carne crua, cuja imagem é destacada em Cronos por sua forte coloração vermelho-escarlate, que remete à sangue humano. Além disso, o antiquário recorre ao estranho objeto para revigorar suas energias, o que acentua a exploração de Del Toro do tema do vampirismo. Mas, ao mesmo tempo que sua força vital é renovada, o verme que habita as engrenagens de Cronos, assemelha-se a uma sanguessuga, alimenta-se do sangue de Gris. Assim, é estabelecida uma relação parasitária entre esse estranho ser de natureza desconhecida e perigosa e Jesús Gris.

Assemelhando-se a monstros, tais como a criatura de Frankenstein, o protagonista do filme de Del Toro transita entre os limites tênues que separam o bem e o mal, além de estar fadado a um inevitável destino trágico. Após ser jogado dentro de um carro em um precipício, Jesús Gris ressuscita, - um evento sobrenatural, que reforça a simbologia de seu nome. Além disso, Gris começa a mostrar aparentes sinais de sua degeneração física. Sua pele começa a desmanchar-se e adquire uma coloração esverdeada. Nota-se que neste trecho do filme, Del Toro destaca a estranha aparência de Gris, de modo que ele evoque a imagem de Christopher Lee, o mais famoso Conde Drácula do cinema.

Na sequência, ele pede ajuda à sua neta, que o acolhe e o protege. Gris refugia-se em caixão que está no interior de um pequeno quartinho cheio de objetos quebrados e não utilizados, localizado em parte de sua casa. Um cenário estranho e decadente que acentua a atmosfera sinistra do filme de Del Toro. 
Mas, a estética gótica em Cronos não aparece somente na imagem do vampiro ou no interior do ambiente doméstico. Ela também se configura no esconderijo do vilão, De La Guardia (Claudio Brook), que sofre de uma doença degenerativa, capaz também de torná-lo um ser monstruoso. Esse personagem mora num quarto improvisado em uma indústria química decorado com várias cópias de estátuas de anjos que, pelo modo como são mostradas pelo diretor, - envolvidas em sacos plásticos, com visíveis sinais da passagem do tempo -, se parecem com cadáveres apodrecidos.

Apesar de concentrar um tempo de sua duração em uma subtrama envolvendo o conflito de Gris com seus inimigos, De La Guardia e seu sobrinho Angel (Ron Perlman que, posteriormente encarnaria um ser monstruoso em Hellboy), que tentam roubar o artefato medieval, Cronos enfatiza o elo que une Jesús Gris a sua neta. Essa ligação emocional revela-se em seu desfecho um elemento essencial para preservar a humanidade de Gris. Quando ele percebe que não irá mais conseguir controlar sua sede por sangue, e assim poderá colocar sua neta em perigo, ele decide acabar com sua própria vida e destruir o estranho artefato. De forma poética, no epílogo do filme, é sugerido que Jesús Gris por meio desse gesto desesperado consegue obter a plena ressurreição de sua carne, representada sob a forma de uma luz celestial que preenche toda a tela no take final.

Em Cronos, podemos encontrar vários ingredientes que compõem a obra cinematográfica de Del Toro: as engrenagens, os objetos autômatos que ganham vida, o mundo infantil em choque com o mundo dos adultos, o medo que as crianças exprimem do 
abandono e da solidão, os seres monstruosos que despertam a compaixão e a simpatia do público expectador.

Outro filme do mesmo diretor que se destaca por seu estilo gótico é A Espinha do Diabo (2001). Ele começa com a imagem impactante de fetos de aparência repulsiva, todos eles contidos em jarros, que apresentaram em sua formação um traço degenerativo, popularmente conhecido como "espinha do diabo" e, por isso, são vistos como aberrações da natureza. Logo depois, o Dr. Cesares (Frederico Luppi) explica a um grupo de garotos que tudo pode ser explicado à luz da Ciência, demonstrando sua descrença na manifestação do sobrenatural. Dentre eles, Carlos (Fernando Tielve) demonstra ser o mais frágil. Ele é vítima de constantes agressões físicas e verbais praticadas pelos internos e também fica assustado com os boatos acerca da existência de um fantasma que teria sido visto à noite andando em um dos corredores do orfanato.

Este cenário é mostrado como decadente, assustador e cheio de mistérios, em que o passado encontra ressonância no tempo presente. O lugar é administrado por Jacinto (Eduardo Noriega), um ex-interno que maltrata e explora os garotos que lá vivem. Apesar da bela aparência que faz com ele consiga exercer um forte poder de atração e domínio sobre as mulheres, Jacinto tem uma natureza maligna e traiçoeira, que estabelece pontos de aproximação entre ele e os vilões das narrativas góticas.

É importante ressaltar que Del Toro ambienta o filme em plena Guerra Civil Espanhola, mundialmente conhecida por seus horrores, tais como execuções à sangue frio e as torturas em prisões de pessoas contrárias ao regime ditatorial de Francisco Franco. No 
pátio do orfanato destaca-se uma enorme bomba atômica, que paira como uma constante ameaça. Em A Espinha do Diabo, sua imagem assustadora, consiste, de acordo com o diretor, em uma metáfora visual: ela é vista pelos garotos como uma espécie de "deusa da fecundidade", uma vez que todos eles são os "Filhos da Guerra" (DEL TORO, 2013, p.111).

Mas, é na cena da aparição do fantasma, de forte impacto visual, que é criado um eficiente efeito de horror. Ele difere de outras criaturas sobrenaturais que aparecem em outros filmes do gênero. Em vez de ser translúcido, o fantasma de $A$ Espinha do Diabo tem aparência humana, com a pele quebradiça e cinzenta, os olhos brilhantes e escuros e em sua testa aparece algo semelhante a um vapor vermelho. Assim, pela forma peculiar como é mostrada, sua imagem consiste em uma manifestação da beleza horrível no filme.

Del Toro salienta que sua intenção foi torná-lo semelhante em sua aparência física a uma boneca quebrada, e assim pudesse dar um aspecto bonito a uma figura monstruosa que poderia ser somente horrivel (2013, p.106). Após uma série de situações envolvendo a busca de Jacinto por uma fortuna em barras de ouro que está escondida no orfanato, A Espinha do Diabo tem seu desfecho no mesmo lugar em que Santi (Junior Valverde) foi morto. É nesse ambiente sinistro, envolvido em sombras, que o vilão do filme é punido em uma cena, em que suscitado o efeito de horror. Nesta, Jacinto submerso dentro de um poço vê o garotofantasma, que reage de forma violenta, agarrando-se ao seu corpo. Na sequência, ele morre afogado nos braços de sua vítima, o que enfatiza o aspecto gótico dessa produção. 
A Espinha do Diabo se encerra com a narração da voz melancólica do professor Casares. Sua última e marcante imagem em um plano aberto mostra o orfanato em escombros e vazio, reforçando a ideia que esse lugar se configura como um espaço fantasmagórico, em que a bomba atômica se mantém intacta, imune à devastadora ação do tempo, pairando como um perigo iminente e assustador.

Após o relativo sucesso de A Espinha do Diabo, que contribuiu para que Del Toro se tornasse um dos grandes diretores mais cultuados do cinema fantástico, ele dirigiu e produziu dois filmes na sequência, Blade I/ e Hellboy que, embora sejam grandes produções de estúdio, trazem sua marca pessoal como realizador. No primeiro, o cineasta retoma e reconfigura elementos da temática vampiresca de Cronos, visando a torná-la mais assustadora. O segundo, uma adaptação de uma história em quadrinhos, revisita o universo mítico e assustador criado por H. P. Lovecraft - cuja obra exerce forte influência sobre às criações de Del Toro.

Ambos se tornaram sucessos de bilheteria e permitem ao diretor dedicar-se ao seu projeto mais pessoal. Trata-se de $O$ Labirinto do Fauno (2006) até então considerado pela crítica especializada sua obra-prima. Para Weeler W. Dixon, este filme de Del Toro estabelece uma relação de proximidade com $O$ Espírito da Colmeia, de Victor Erice, que, por seu turno, dialoga com a versão cinematográfica de Frankenstein, lançada nos cinemas em 1931. Dixon salienta que as duas produções são protagonizadas por meninas indefesas que vivem dentro de uma realidade brutal e tentam se refugiar em um mundo encantado habitado por seres sobrenaturais para se sentirem seguras e protegidas (2010, p.184). 
Também nos dois filmes ocorrem situações extraordinárias que, pela forma como são narradas, não é possível determinar se elas são reais ou somente ilusões criadas pela imaginação das protagonistas. Nesta perspectiva, o filme de Del Toro insere-se na esfera do fantástico, pelo viés de Todorov. De acordo com o conceito de Tzvetan Todorov o fantástico consiste em um evento que se caracteriza pela incerteza. Sendo assim, ele admite duas possibilidades de interpretação: pode ter uma origem sobrenatural ou é explicado pelas leis naturais (2004, p.30-31).

O Labirinto do Fauno alterna a realidade e a fantasia, de modo a provocar uma constante hesitação no espectador. Em sua primeira cena, aparece seu principal cenário, que dá o título ao filme, com contornos sobrenaturais em contraste com a imagem do rosto quase inerte em close de Ofélia (Ivana Baquero). Logo depois, uma voz em off (do ator Frederico Luppi) narra de forma sucinta um conto de fadas. Neste, a princesa de um reino mágico e subterrâneo, quando vem à superfície da Terra para conhecer seus habitantes, perde a memória e fica presa no mundo real.

É importante enfatizar que o filme de Del Toro, assim como em A Espinha do Diabo, é ambientado no auge da Guerra Civil Espanhola. Na sequência é mostrada a chegada de Ofélia e sua mãe Carmem (Ariadna Gil) a um moinho. Elas são levadas até esse lugar, que em alguns aspectos se assemelha a um castelo medieval, pelo capitão Vidal (Serge Lopes), com propósito de descobrir e aniquilar um exército de milícia, que está atuando na região.

Vidal reúne em sua personalidade todas as características negativas de um vilão gótico: é vaidoso, egocêntrico e cruel. Além 
disso, sua aparência remete a do ditador espanhol Francisco Franco, o que reforça o aspecto metafórico do filme. Como Manfred, o sinistro protagonista de 0 Castelo de Otranto, ele é obcecado pela continuidade de sua linhagem familiar. Assombrado pela figura do pai também militar que morreu em combate, Vidal guarda o relógio que pertenceu a ele. Vidal deseja morrer como um herói de guerra no mesmo horário que seu pai, de modo a ser imortalizado na História. Além disso, o sádico militar mantém Ofélia e Carmem sob sua constante vigilância, tornando-as suas prisioneiras.

Apesar de esforçar-se por insistência de sua mãe, a menina não consegue estabelecer uma relação de afeto com seu padrasto. Ofélia o vê com repulsa e até mesmo temor. Ela é uma leitora compulsiva de contos de fada, o que causa uma profunda irritação em Vidal, pois ele acredita que tais leituras podem encher a cabeça da menina de bobagens. Assim que chega ao lugar, ela é atraída por um inseto até um cenário em ruínas: é o labirinto que, de acordo com uma das empregadas, Mercedes (Maribel Vérdu) é tão velho que não é possível saber quando surgiu.

A partir do momento em que Ofélia entra em contato com esse local antigo e mítico, que se destaca por sua aparência bela e assustadora ao mesmo tempo, começa a ocorrer uma série de estranhos eventos. Na sequência, ela é visitada pelo fauno que habita o labirinto. Ele diz que Ofélia é na verdade a princesa que habitava o mundo subterrâneo e para voltar para lá terá que realizar três tarefas. Nessa ocasião, a criatura entrega à menina um livro mágico, - um elemento que alude ao processo criativo do próprio diretor -, que contém instruções sobre o que ela terá que fazer. 
Dessa forma, Ofélia é inserida em um mundo mágico, que gradativamente revela-se muito assustador e assemelha-se em alguns aspectos aos reinos encantados descritos nas narrativas dos irmãos Grimm, tais como O rapaz que não sentia calafrios. Trata-se de uma história dos Grimm que pode ser considerada "gótica", uma vez que grande parte de seu enredo se passa no interior de um castelo mal-assombrado.

Vale lembrar que nos enredos dos contos de fadas originais destacavam-se o aparecimento de criaturas monstruosas, cenas de canibalismo e atos de violência e crueldade contra às mulheres e crianças, a exemplo da tentativa da bruxa de matar Branca de Neve, fazendo uso de uma maça envenenada. Tais elementos assustadores e recorrentes nessas narrativas são retomados em várias passagens de $O$ Labirinto do Fauno.

Também nessa sequência surreal do filme, aparecem elementos que remetem a Alice no país das maravilhas, de Lewis Carroll. O vestido dado à menina por sua mãe é uma cópia fiel daquele usado por Alice - de acordo com o visual atribuído a essa personagem a partir das ilustrações de John Tenniel. Além disso, Ofélia, de forma semelhante a Alice, se vê diante de situações extraordinárias que não consegue entender plenamente.

Na primeira tarefa, a menina para atingir seu objetivo, que consiste em obter uma chave de ouro, é obrigada a enfrentar um sapo gigante e repulsivo. Na segunda, a pior delas, a garota desafia um monstro canibal que evoca as criaturas sinistras dos contos de H. P. Lovecraft. É no visual grotesco desse ser monstruoso que o diretor retoma com grande força a estética da beleza do horrível 
em seu filme. A criatura tem uma aparência muito estranha, criada a partir da combinação de vários elementos grotescos (mãos muito grandes, cabeça oval, pernas e braços desproporcionais), que o tornam horrivelmente belo.

Quando Ofélia consome um dos alimentos que estão em uma mesa, o monstro desperta e para poder enxergar insere os olhos nas palmas das mãos - uma cena de contornos surrealistas que novamente remonta ao universo dos contos de fadas. Na sequência, no trecho mais tenso e claustrofóbico do filme, o monstro persegue Ofélia no interior de um apertado corredor, e somente com a criação de uma porta mágica, a menina consegue evitar que ele a devore.

Apesar de haver muitas sequências assustadoras ambientadas no mundo encantado, os efeitos de horror em $O$ Labirinto do Fauno concretizam-se de forma mais intensa na esfera da realidade, em cenas de extrema violência. Em uma delas, a mais chocante, um soldado tem os dedos da mão quebrados pelo capitão Vidal, que demonstra um prazer sádico, quando pratica atos de tortura ou mata à sangue frio seus inimigos. Neste aspecto, ele é tão monstruoso e perigoso como os monstros que Ofélia encontra durante o cumprimento de suas tarefas.

Esta associação entre Vidal e as criaturas sobrenaturais que aterrorizam a menina ressalta a conotação metafórica do horror no filme de Del Toro. O fauno, o grotesco sapo, e, principalmente - monstro cego, que se alimenta de crianças podem ser compreendidos como duplos de Vidal. Assim, visto pela ótica de Ofélia, seu padrasto torna-se uma espécie de "bicho papão" que deseja devorá-la. Vidal é a criatura mais horrenda e terrível de 
O labirinto do Fauno. A imagem do rosto deformado do militar é enfatizada por Del Toro para atestar sua natureza monstruosa. Além disso, ele também demonstra resistência à morte, reforçando a ideia no filme que esse personagem representa um Mal ideológico, difícil de ser totalmente exterminado.

Após fugir com o bebê recém-nascido, Ofélia retorna ao labirinto e encontra-se com o fauno para cumprir a última tarefa que Ihe foi imposta. Lá, a menina toma conhecimento que para retornar ao reino subterrâneo, ela terá que usar a adaga, - o objeto obtido em seu confronto com o monstro cego -, para tirar uma pequena quantidade de sangue de seu irmão. Diante desse ato de crueldade, Ofélia demonstra uma reação de revolta e recusa-se a machucar a criança. Neste momento, Vidal vê Ofélia falando sozinha, suscitando dúvidas no espectador sobre a veracidade desse evento extraordinário. Nota-se que a cena é vista pelo olhar do outro personagem (Vidal) que, diante da menina, não vê o fauno.

Logo depois, ele atira na enteada atingindo-a no peito. Antes da menina cair ao chão mortalmente ferida, Vidal pega o bebê e foge. Contudo, quando está saindo do labirinto, o militar é cercado pelo exército de milícia. Sabendo que irá ser executado, ele pede que Mercedes entregue o relógio que marca o horário de sua morte para seu filho. A moça temendo dar continuidade ao legado sangrento do militar, diz a ele que o menino nunca saberá o nome de seu pai biológico. Em seguida, Vidal morre executado, sem conseguir o que mais deseja: ter seu nome perpetuado na História como herói de guerra. 
Apesar da alta carga de brutalidade e violência desta sequência, o desfecho de $O$ Labirinto do Fauno é comovente e poético. Em seu epílogo, Ofélia se vê no mundo subterrâneo e toma conhecimento de que obteve sucesso no cumprimento de sua última tarefa. A menina aparece caracterizada como uma princesa de contos de fadas e vê seu pai (Frederico Luppi) e sua mãe, ambos falecidos no mundo real, sentados em tronos de ouro.

No entanto, podemos perceber que essa cena que faz uma referência $O$ Mágico de $\mathrm{Oz}$ em seu aspecto visual, - Ofélia usa sapatinhos vermelhos como Dorothy -, e representa o final feliz no filme alterna-se com outra, de aspecto realista, em que Ofélia aparece morrendo abraçada junto a Mercedes. Assim, apesar da ênfase dada às situações extraordinárias vivenciadas pela protagonista, temos a forte tendência a achar que elas são somente ilusões criadas pela garota com o propósito de fugir da cruel realidade que a cerca. Mas, essa certeza novamente é desfeita na imagem que encerra $O$ Labirinto do Fauno. Nela, destaca-se o surgimento de uma flor branca, - um símbolo da inocência de Ofélia, que remonta aos contos de fadas -, no caule da árvore seca e morta habitada pelo sapo grotesco exterminado pela menina.

Novamente, Del Toro confere a esse encerramento uma significação metafórica: é a garotinha sonhadora que deixou seu legado e não o cruel militar que fez de tudo para que isso acontecesse. Assim, em $O$ Labirinto do Fauno é enfatizado o triunfo da imaginação sobre os horrores que têm suas origens na vida real.

Também nessa produção dirigida por Del Toro transparece uma mensagem recorrente nos contos de fadas: nossas escolhas 
definem nosso destino, e somente por meio do sacrifício e da bondade, nós somos capazes de enfrentar e superar os perigos e as dificuldades. Como se vê, $O$ Labirinto de Fauno tem todos os elementos essenciais de um conto de fadas. Por outro, trata-se de um conto de fadas sombrio, em que se sobressaem situações assustadoras. Neste aspecto, podemos dizer que $O$ Labirinto do Fauno tem matizes góticas. Dessa forma, Del Toro cria um instigante jogo de espelhamento, em que a fantasia encontra forte ressonância no mundo real. O mundo mágico de Ofélia pode ser compreendido como um espelho distorcido do mundo real, marcado por situações brutais e absurdas, que revelam o lado sinistro da realidade.

\section{CONSIDERAÇÕES FINAIS}

Neste artigo, fiz uma pequena exposição de alguns aspectos peculiares e importantes para que possamos entender melhor a estética de horror sublime dos filmes de Guillermo Del Toro. Del Toro por meio dela retoma e lança um novo olhar sobre os motivos e temas que podem ser encontrados no gótico, em suas manifestações no cinema e na literatura e também nos contos de fadas. Em seus filmes, mesmo aqueles voltados para o circuito comercial, o diretor sempre deixa registrado um toque pessoal, seja no modo como consegue extrair beleza daquilo que somente poderia ser horrível ou como retrata os protagonistas, que se assemelham aos personagens solitários e sonhadores dos romances de Charles Dickens e das narrativas de Lewis Carrol.

Os seres monstruosos de Cronos e A Espinha do Diabo (o vampiro infeliz Jesús Gris, Santi, o solitário garoto-fantasma) evocam figuras icônicas do horror gótico, principalmente, a criatura 
de Frankenstein que, apesar da aparência horrenda, não é má e tudo que deseja é ser aceita e amada. Isso demonstra que o próprio diretor se identifica com o que é diferente, estranho, anormal, ou considerado fora dos padrões convencionais de beleza.

É nesta mistura criativa e equilibrada de elementos assustadores e ao mesmo tempo atraentes ao olhar do expectador, que tem seu surgimento no terror/horror gótico, sobrenatural, macabro, onírico e também no maravilhoso, no qual podemos encontrar a matériaprima da obra cinematográfica de Guillermo Del Toro. Como um mago dos tempos modernos, Del Toro demonstra seu toque de magia, reunindo de forma harmoniosa todos esses ingredientes em filmes inesquecíveis e assustadores que contribuíram de forma significava para estabelecer os novos rumos do cinema fantástico na época atual.

\section{REFERÊNCIAS}

BOTTING, Fred (1996). Gothic. Londres: Routledge.

BURKE, Edmund (1993). Uma investigação filosófica sobre a origem de nossas idéias sobre do sublime e do belo. Tradução de Enid Abreu Dobránzky. Campinas, SP: Papirus.

CARROLL, Noël (1999). A filosofia do horror ou paradoxos do coração. Tradução de Roberto Leal Ferreira. Campinas, SP: Papirus.

DEL TORO, Guilhermo; ZICREE, Scott Mark. Guillermo Del Toro: Cabinet of Curiosities - My Notebooks, Collections e Others Obsessions. Nova York: Harper Collins.

DIXON, Winston Wheeler (2010). A history of horror. Nova Jersey: Rutgers University Press.

HAGgerTY, George E. (1989). Gothic Fiction/Gothic Form. Pennsylvania: Pennsylvania University Press. 
KEMP, Phillip (org.) (2011). Tudo sobre cinema. Rio de Janeiro: Sextante.

PRAZ, Mario (1999). O diabo, a carne e a literatura romântica. São Paulo: Editora da UNICAMP.

TODOROV, Tzvetan (2004). Introdução à literatura fantástica. São Paulo: Perspectiva.

WOODS, A. Paul (2011). O estranho mundo de Tim Burton. São Paulo: Leya. 